\title{
The Value of PET-CT Scan in Determining Remission Status in Lymphoma Patients Involving the Head \& Neck Region
}

(Penilaian Imbasan PET-CT dalam Menentukan Status Sembuh di Bahagian Kepala \& Leher Pesakit Limfoma)

WAN FARIZA WAN JAMALUdin*, FARA RAHIDAH HuSin, Aini AB. AZIZ, MOHD RaZIF MOHD YunUS,

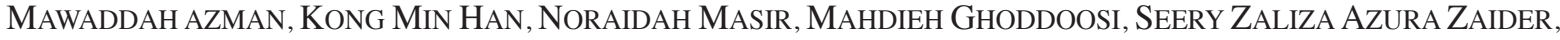
NORMI MUSTAPHA, NOR ASIAH MUHAMAD \& S FADILAH ABDUL WAHID

\begin{abstract}
In lymphoma, Positron Emission Tomography-Computerized Tomography (PET-CT) provides greater prognostic information than conventional imaging. However, false positivity occurred particularly in the head \& neck due to predilection for infection and inflammation. We investigated the association between positive scans in the head \& neck at the end of therapy with histology, and its diagnostic and prognostic values. 488 PET-CT were retrospectively assessed in 2012-2016 (40 months). Positive uptakes in the head \& neck (five-point scale $\geq 4$ ) were biopsied. Prevalence of positive scans was $10.9 \%$ (53/488). Two positive scans were histologically lymphomatous with mean maximum standardized uptake value (SUVmax) of 9.0 \pm 2.69 . False positivity (96.2\%) was histologically attributed to reactive lymphoid hyperplasia (SUVmax

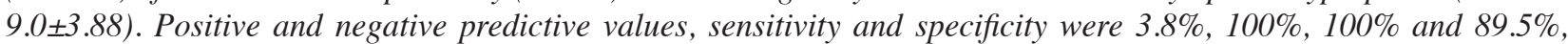
respectively. False positivity was associated with age, gender, extra-nodal involvement, Eastern Cooperative Oncology Group score (ECOG), positivity only in the head \& neck and its pattern of positivity. No significant predictors were identified. Hodgkin Disease (HD) was more likely to have positivity only in the head \& neck compared to Non-Hodgkin Lymphoma (NHL) ( $p=0.019)$. 106 patients with negative scans remained negative during study period, hence regarded as true negatives. Positive scans in the head \& neck at post therapy yielded high false positivity and should not be routinely performed. HD has higher likelihood of scan positivity only in the head \& neck than NHL. The value of PET-CT to detect true lymphomatous relapse in selected high-risk patients remained to be confirmed in future trials.
\end{abstract}

Keywords: Head \& neck; lymphoma; PET-CT

\section{ABSTRAK}

Dalam limfoma, imbasan Positron Emission Tomography-Computerized Tomography (PET-CT) memberi maklumat prognosis yang lebih mendalam berbanding imbasan konvensional. Namun, keputusan positif palsu berlaku terutama di bahagian kepala \& leher kerana tisu limfoid di situ sering terdedah kepada radang dan jangkitan. Kami mengkaji hubung-kait antara imbasan positif di bahagian kepala \& leher dengan histologi serta nilainya dalam maklumat diagnostik dan prognostik. 488 imbasan PET-CT setelah rawatan tamat telah dikaji secara retrospektif antara 2012-2016 (40 bulan). Imbasan positif di kepala \& leher (skor berskala lima $\geq 4$ ) dihantar untuk biopsi. Kelaziman imbasan positif ialah $10.9 \%$ (53/488). Hanya dua imbasan positifterbukti mengandungi histologi limfoma, dengan bacaan SUVmax 9.0 +2 .69. Imbasan positif palsu (96.2\%) mengandungi histologi limfoid hyperplasia reaktif (SUVmax 9.0 3.88 ). Nilai ramalan positif dan negatif, kesensitifan dan kekhususan adalah 3.8\%, 100\%, 100\% dan 89.5\%. Imbasan positif palsu dikaitkan dengan umur, jantina, penglibatan extra-nodal, ECOG, positif di kepala \& leher sahaja, dan corak positif, namun tiada faktor peramal dapat dikenal pasti. Hodgkin Disease (HD) dikenal pasti sebagai peramal untuk mempunyai imbasan positif di kepala \& leher sahaja berbanding Non-Hodgkin Lymphoma (NHL) ( $p=0.019) .106$ pesakit yang mempunyai imbasan negatif kekal sembuh sepanjang tempoh kajian, maka mereka dianggap sebagai negatif tulen. Kesimpulannya, imbasan positif di kepala \& leher selepas tamat rawatan menunjukkan kadar positif palsu yang tinggi dan tidak harus dijalankan secara rutin. HD lebih berkemungkinan tinggi untuk mendapat imbasan positif di kepala \& leher sahaja berbanding NHL. Nilai imbasan PET-CT untuk mengesan limfoma berulang dalam kalangan pesakit berisiko tinggi harus dikaji lagi dalam penyelidikan pada masa akan datang.

Kata kunci: Kepala \& leher; limfoma; PET-CT

\section{INTRODUCTION}

The role of PET-CT scan in assessing residual mass after completion of first line therapy in fluorodeoxyglucose avid (FDG) lymphomas is recognized to be superior to conventional imaging and is incorporated into the International Working Group revised response criteria for malignant lymphoma (Cheson et al. 2014). In CT or Magnetic Resonance Imaging (MRI), up to $64 \%$ of HD and 
$60 \%$ of NHL would have the uncertainty whether or not a complete remission have been achieved (Zinzani et al. 2009). Early recognition of pre-clinical relapse would allow for timely administration of salvage therapy to improve survival, and late effects of radiotherapy may be spared if a residual mass is proven not to contain active disease (Rahmouni et al. 2005). PET is a 3-dimensional scan that utilizes FDG, a glucose analogue in combination with ${ }^{18}$ Fluorine isotope with gamma rays' emission. Biologically active cells take up the ${ }^{18}$ FDG for metabolism and the concentration and location of the uptakes gives an indication of tumor activity. PET scan combined with contrast-enhanced CT scan allows for both metabolic and anatomical images to be analyzed simultaneously. ${ }^{18}$ FDG utilization arises from observations of increased glycolysis in tumor cells due to upregulation of glucose transporter expressions (Ancey et al. 2018). Although glucose concentration is most marked within tumors, immune cells e.g. macrophages and neutrophils can also accumulate glucose. Therefore, ${ }^{18}$ FDG uptake into inflammatory lesions can cause false positivity and need to be interpreted with caution (Schaefer et al. 2007). The amount of ${ }^{18} \mathrm{FDG}$ uptake is relative to the amount injected and patient's body size. SUVmax is a mathematical formula used as a relative measure of in-vivo ${ }^{18} \mathrm{FDG}$ uptake. Healthy lymphatic tissues may display low to moderate SUVmax in the head \& neck region (lingual/palatine tonsils and base of tongue) due to physiological activity in Waldeyer's ring (Sarji 2006). These sites are commonly involved in malignant lymphoma, however they also have a predilection for inflammation/infection and may cause false positivity on PET-CT. Additionally, false positivity may occur after granulocyte colony stimulating factor therapy (G-CSF), radiotherapy, after operation, fracture, degenerative changes and contrast injection leakage (Kazama et al. 2005). Currently there are no definite parameters in PET-CT to rule out lymphomatous lesions except via tissue biopsy. Tissue biopsy and histopathological examination is the current gold standard to confirm presence of lymphoma. Therefore, this study was conducted to determine the value of PET-CT scan in determining remission status in lymphoma patients involving the head \& neck region.

\section{MATERIALS AND METHODS}

\section{STUDY DESIGN}

A cross-sectional single centre study was conducted in Universiti Kebangsaan Malaysia Medical Center (UKMMC) from January 2012 to May 2016 (40 months). A total of 488 PET-CT scans at post therapy and surveillance performed in FDG-avid lymphoma patients were retrieved from hospital registry. Post therapy PET-CT was performed 6-8 weeks after chemotherapy and 3-6 monthly during surveillance period. Positive PET-CT in the head \& neck region was defined by Deauville Criteria which consisted of five-point scale (FPS) and reported by a trained and experienced nuclear medicine physician without knowledge of histology. An FPS score of 4 or 5 was considered positive and referred for definitive biopsy. FPS score of 1, 2 and 3 were considered negative. Signed written consent form was obtained for imaging and biopsy. This study was approved by UKMMC Medical Research Ethics Committee (FF-2014-388).

\section{IMAGING PROCEDURES}

All patients fasted for a minimum $6 \mathrm{~h}$ before PET-CT study. Fasting serum glucose levels were kept between 5-9 $\mathrm{mmol} / \mathrm{L}$. Any forms of exercises were avoided for at least $24 \mathrm{~h}$ prior the procedure. Intravenous administration of ${ }^{18} \mathrm{FDG}$ was calculated based on patient's body weight; $45 \mathrm{~kg}-70 \mathrm{~kg}(10 \mathrm{mCi})$, less than $45 \mathrm{~kg}$ or more than $70 \mathrm{~kg}$ $(0.2 \mathrm{mCi} / \mathrm{kg})$. Patients were kept supine in a well resting position under low ambient light for one hour prior to the scan. PET images were acquired with Discovery 690 PET CT machine (GE Healthcare). CT images were obtained from vertex to mid-thigh and were used as attenuation correction. The CT parameters were KV 140 with autom A ranging from 40-120 according to body region. Subsequently, FDG PET images were acquired from mid-thigh to vertex in 7-8 bed positions depending on patients' body habitus. Three minutes were dedicated in each bed position for all areas except one minute for bed position of extremities. PET images were reconstructed using OSEM, point of spread function as well as time of flight reconstruction algorithm. PET-CT was postponed if patients were suspected or suffered from infections until complete recovery.

\section{IMAGE ANALYSIS}

PET-CT images were independently reviewed by a consultant nuclear medicine physician without knowledge of histology. Image interpretation included visual inspection in conjunction with SUVmax of the positive lesions. SUV was defined as FDG accumulation within the region of interest over the corrected dose administered by body weight. SUVmax corresponded to the highest image pixel in the positive uptake area. The positive lesions were those of which demonstrated asymmetrical positive uptake and were considered positive visually, and semi quantitatively is higher than that of the liver. PET-CT scans were reported as negative when no pathological uptake seen and semi quantitatively lesser than that of the liver. Visual assessment were numerically categorized using the five-point scale based on Deauville criteria (Moskowitz 2012).

\section{BIOPSY}

Patients with positive PET-CT involving the head \& neck region were referred to ear, nose and throat (ENT) surgeon. Core tissue biopsies, lymph node excision or adenoidectomy/tonsillectomy were performed to 
corresponding head \& neck areas e.g. tonsils, tongue base, Fossa of Russenmuller and adenoids under local or general anesthesia, as per standard protocol in ENT Department, UKMMC (Myers 2010). Patients with negative PET-CT scans were not subjected to tissue biopsy to confirm true negativity.

\section{HISTOPATHOLOGICAL ANALYSIS}

All biopsies were examined and reported by a consultant histopathologist without knowledge of PET-CT results. The hematoxylin and eosin (H\&E) stained slides were examined and reported into one of the followings; reactive lymphoid hyperplasia or malignancy. Immunohistochemical staining or molecular studies including in-situ hybridization technique were performed as indicated. Positive biopsy was defined as lymphomatous infiltration confirmed with immunohistochemical stains.

\section{DATA COLLECTION}

A standardized form was used to extract the following data; age, gender, lymphoma subtype, stage, ECOG, B symptoms at diagnosis, extra-nodal involvement, rituximab therapy, positivity only in the head \& neck and the pattern of positivity in the head \& neck, and analyzed with Statistical Package for Social Science (SPSS) version 21. Basic characteristics were identified using descriptive statistics. Univariate and multivariate analyses were performed using simple and multiple logistic regressions to determine associations and predictors.

\section{RESULTS}

\section{PATIENTS' CHARACTERISTICS}

The study algorithm is illustrated in Figure 1. A total of 488 PET-CT scans were performed in a total of 159 patients with FDG-avid lymphoma after completion of first line therapy and during surveillance with follow up period of 40 months. The characteristics of patients with positive uptake in the head \& neck (patients $n=53$ ) were shown in Table 1 . The mean age was $43 \pm 17$ years (range 15-71), and 12 patients $(22.6 \%)$ were $\geq 60$ years. Based on Ann Arbor staging, 30 patients $(56.6 \%)$ had advanced stages of III and IV, whilst 23 patients (43.4\%) had early stages I and II.

\section{DIAGNOSTIC VALUE OF PET-CT}

The diagnostic value of PET-CT in the head \& neck region at post therapy and during surveillance in relation to tissue biopsy is tabulated in Table 2 . The prevalence of positive PET-CT in the head \& neck was $10.9 \%$ (53/488). Only two PET-CT were histologically confirmed as relapse lymphoma with subtypes of NHL, and both scans were positive at the nasopharynx region. The false positivity (FP) was $96.2 \%$ (51/53). The positive predictive value (PPV) was 3.8\%, while the negative predictive value (NPV) was $100 \%$. The sensitivity was $100 \%$ and the specificity was $89.5 \% .106$ patients with negative PET-CT in the head \& neck region during post therapy and surveillance were followed up and remained negative throughout the study period, therefore were regarded as true negatives (TN) (Avivi et al. 2013).

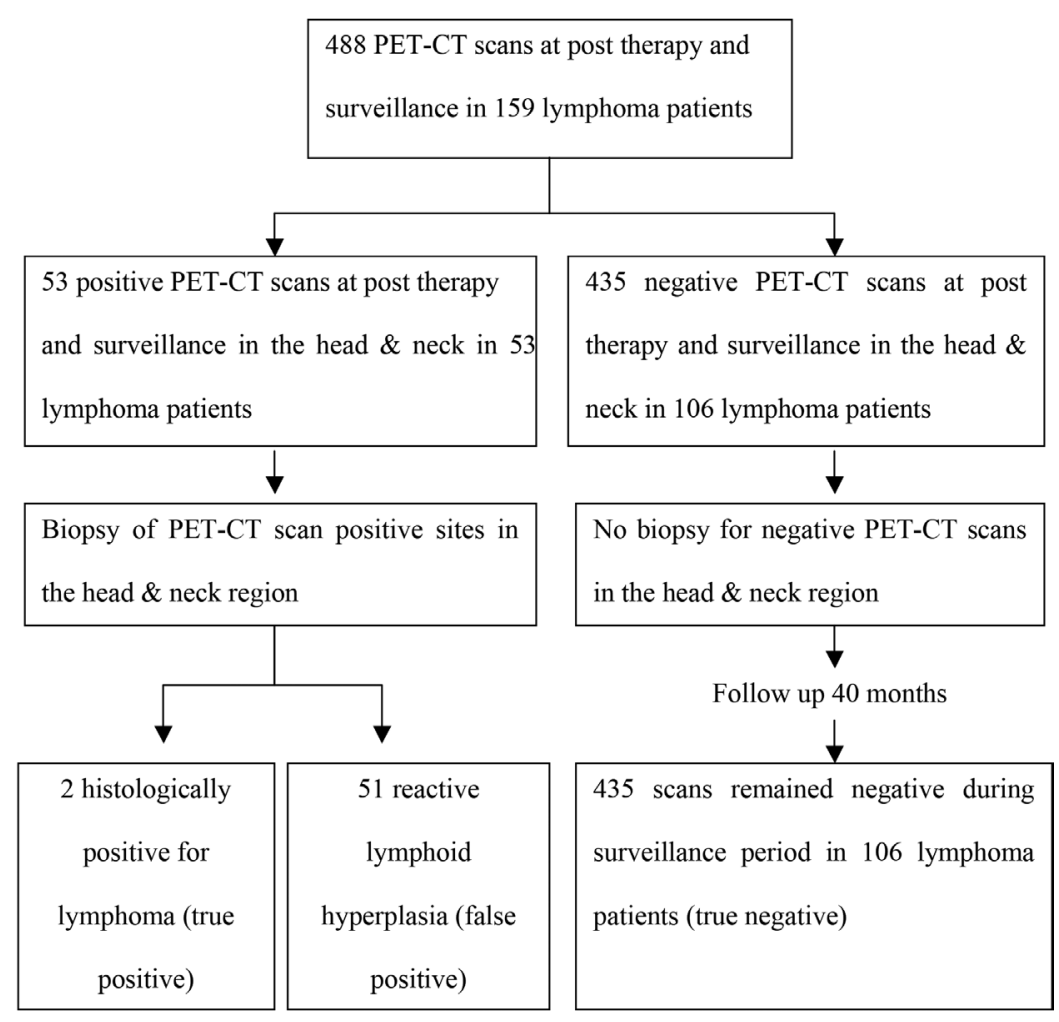

FIGURE 1 . The study algorithm 
TABLE 1. Clinical characteristics of patients with positive PET-CT in the head \& neck region at post therapy and surveillance (patients $n=53$ )

\begin{tabular}{lccc}
\hline & Variable & $\begin{array}{c}\text { Frequency } \\
(\mathrm{n}=53)\end{array}$ & Percent $(\%)$ \\
\hline Age & $<60$ years & 41 & 77.4 \\
Gender & Male & 12 & 22.6 \\
Stage & Female & 27 & 50.9 \\
& I, II & 26 & 49.1 \\
Subtype & III, IV & 23 & 43.4 \\
lymphoma & HD & 30 & 56.6 \\
Extra-nodal & NHL & 20 & 37.7 \\
involvement & No & 33 & 62.2 \\
ECOG & Yes & 20 & 62.3 \\
& $<2$ & 52 & 37.7 \\
B symptoms at & $\geq 2$ & 1 & 98.1 \\
diagnosis & No & 20 & 1.9 \\
Rituximab & Yes & 33 & 37.7 \\
therapy & No & 23 & 62.3 \\
Pattern of & Yes & 30 & 43.4 \\
positivity in & Nasopharynx & 19 & 56.6 \\
head \& neck & Oropharynx & 34 & 35.8 \\
Positivity in & & & 64.2 \\
head \& neck & Head \& neck, & 39 & \\
only & and other sites* & & \\
& Head \& neck & 14 & 73.6 \\
\hline
\end{tabular}

*Definition of other sites: lymph nodes in the abdomen / mediastinum / inguinal regions

No false negative (FN) scans occurred throughout the study period (Schaefer et al. 2007).

\section{SUVmax VALUES}

The mean SUVmax of histopathologically proven relapsed lymphoma was $9.0( \pm 2.69)$ (Figure 2(a) and 2(b)), while mean SUVmax of the reactive lymphoid hyperplasia lesions was $9.0( \pm 3.88)$ (Figure 3(a) and 3(b)).

\section{FACTORS ASSOCIATED WITH PET-CT POSITIVITY IN THE HEAD \& NECK REGION}

Univariate analysis showed that PET-CT positivity in the head \& neck region at post therapy and surveillance was significantly associated with age $(\mathrm{p}<0.01)$, gender $(\mathrm{p}<0.01)$, ECOG $(\mathrm{p}<0.01)$, extra-nodal involvement $(\mathrm{p}<0.01)$, positivity only in the head $\&$ neck $(\mathrm{p}=0.013)$ and its pattern of positivity $(\mathrm{p}=0.004)$ (Table 3(a)). However, multivariate analysis did not identify any significant predictors for PET-CT positivity in the head \& neck region at post therapy and surveillance (Table 3(b)).

\section{SUBGROUP ANALYSIS FOR PET-CT POSITIVITY ONLY IN THE HEAD \& NECK REGION}

$14 / 53(26.4 \%)$ PET-CT scans were positive only in the head $\&$ neck region with no concomitant positivity in other sites
(Table 1). Age, gender, stage of the disease, lymphoma subtypes, extra-nodal involvement, ECOG, presence of B symptoms at diagnosis, rituximab therapy and pattern of positivity in the head \& neck were significantly associated with PET-CT positivity only in the head \& neck (Table 4(a)). Multivariate analysis showed that HD was more likely to have positive PET-CT only in the head \& neck region compared to NHL $(\mathrm{p}=0.019)$ (Table 4(b)).

\section{DISCUSSION}

PET-CT is a non-invasive diagnostic tool that provides both anatomical and metabolic tissue characterizations that is useful in distinguishing between viable tumor in anatomically normal organs from necrosis and fibrosis in residual mass (Fadilah 2009; Han et al. 2008). The role of PET-CT in response assessment in Diffuse Large B Cell Lymphoma (DLBCL) and HD was introduced in 2007 by the International Harmonization Project (IHP) (Cheson et al. 2007), and the staging and response criteria was revised using Lugano criteria in 2014 (Barrington et al. 2014; Cheson et al. 2014).

PET-CT is interpreted using qualitative visual assessment and determination of semi-quantitative SUVmax that reflects the degree of tumor FDG avidity and is linked to tumor's aggressiveness. The FPS criteria improves 

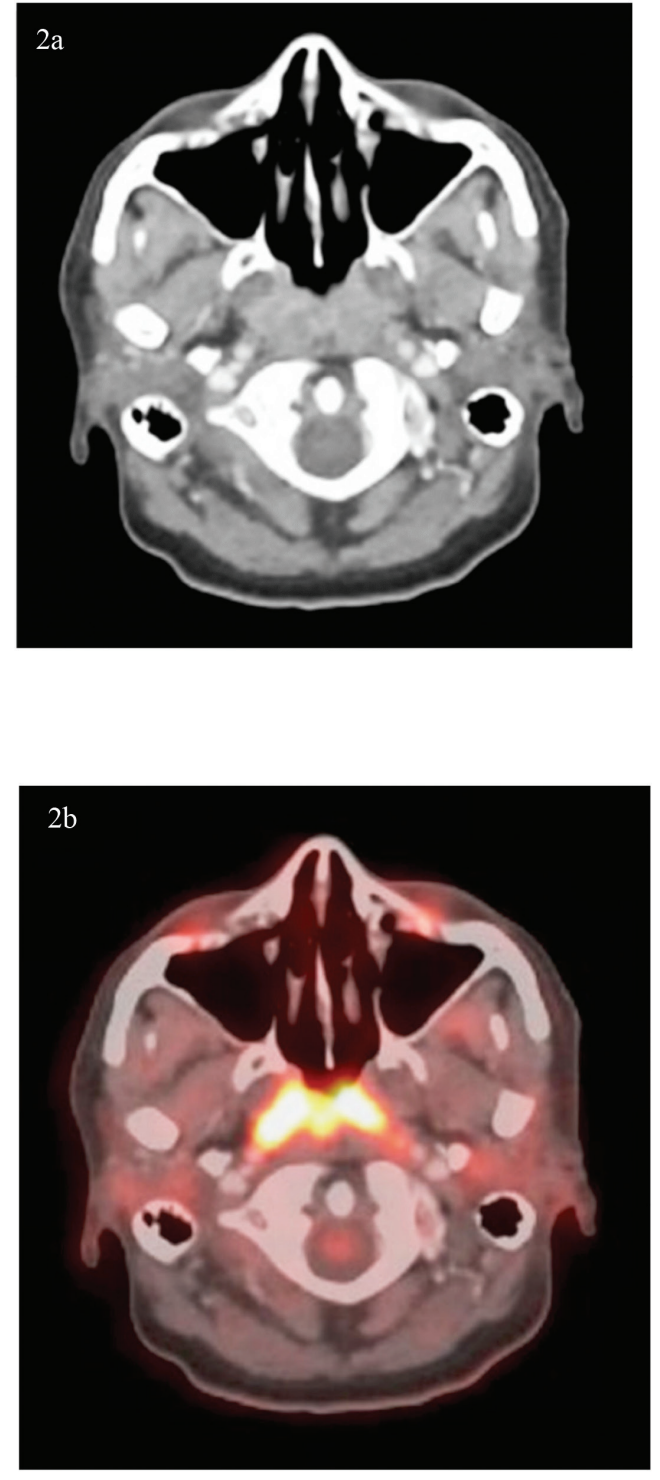

FIGURE 2. CT (2a) and PET-CT (2b) images showing axial section of head \& neck region where the nasopharyngeal space is seen diffusely thickened and hypermetabolic, where the mean SUVmax value for true positive lesions were $9.0 \pm 2.69$
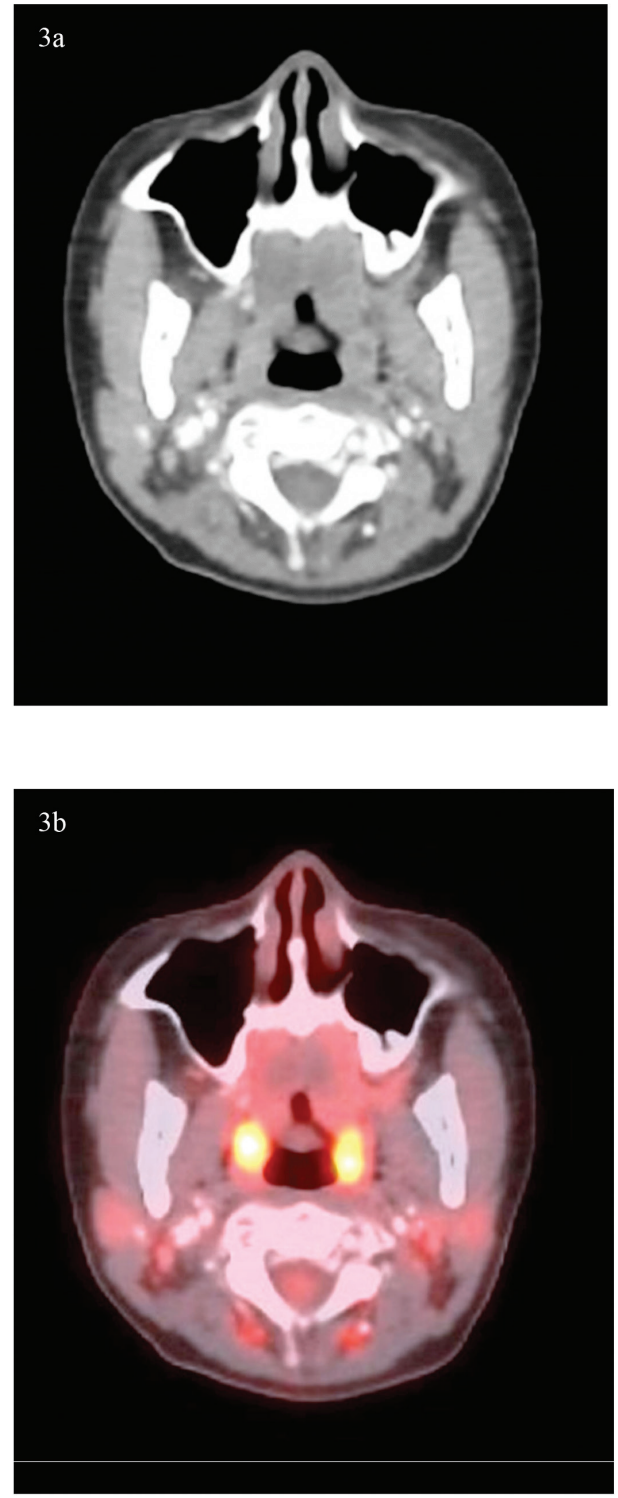

FIGURE 3. CT (3a) and PET-CT (3b) images showing axial section of head $\&$ neck region at the oropharyngeal space with hypermetabolism without morpho-structural changes on CT, where the mean SUVmax value for false positive lesions were $9.0 \pm 3.88$

TABLE 2. The diagnostic values of PET-CT scan in the head \& neck region at post therapy and surveillance

\begin{tabular}{|c|c|c|c|}
\hline \multirow{2}{*}{ PET-CT Scan } & \multicolumn{2}{|c|}{ Biopsy } & \multirow{2}{*}{ Total } \\
\hline & Positive & Negative & \\
\hline Positive & 2 (ТP) & $51(\mathrm{FP})$ & 53 \\
\hline Negative & $0(\mathrm{FN})$ & $* 435(\mathrm{TN})$ & 435 \\
\hline TOTAL & 2 & 486 & \\
\hline
\end{tabular}

TF: true positive, FP: false positive, FN: false negative, TN true: negative

*True-negativity based on 435 negative PET-CT scans at end of therapy that remained negative during study follow-up (Avivi et al. 2013)

\begin{tabular}{lcccc}
\hline & Sensitivity & Specificity & PPV & NPV \\
\hline $\begin{array}{l}\text { PET-CT in the } \\
\text { head \& neck }\end{array}$ & $100 \%$ & $89.5 \%$ & $3.8 \%$ & $100 \%$ \\
\hline
\end{tabular}

PPV: positive predictive value, NPV: negative predictive value 
TABLE 3. (a) Simple logistic regression analysis for factors associated with PET-CT positivity in the head \& neck region at post therapy and surveillance

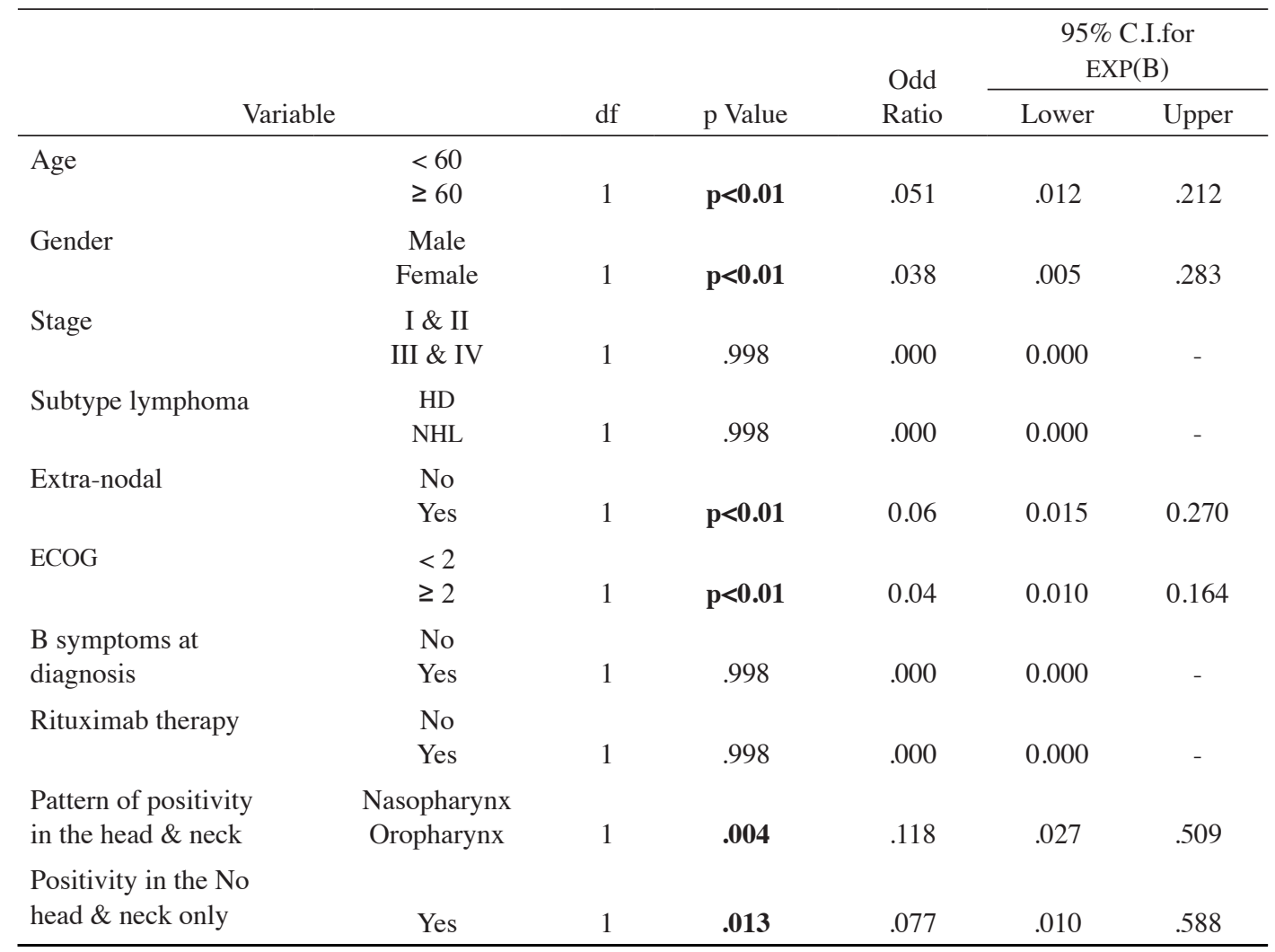

Significant when $\mathrm{p}<0.05$

TABLE 3. (b) Multiple logistic regression analysis showed that no significant factors were identified as a predictor for PETCT positivity in the head \& neck region at post therapy and surveillance

\begin{tabular}{|c|c|c|c|c|c|c|c|}
\hline & & & & & Adjusted & $\begin{array}{r}95 \% \\
\mathrm{E}>\end{array}$ & $\begin{array}{l}\text { I.for } \\
\text { B) }\end{array}$ \\
\hline & & B & df & $\mathrm{p}$ Value & Odd Ratio & Lower & Upper \\
\hline Age & $<60$ & & & & & & \\
\hline & $\geq 60$ & 0.012 & 1 & .995 & 1.012 & .026 & 39.785 \\
\hline Gender & Male & & & & & & \\
\hline & Female & -.962 & 1 & .497 & .382 & .024 & 6.129 \\
\hline Extra-nodal & No & & & & & & \\
\hline & Yes & 18.329 & 1 & .998 & 91226623.0 & .000 & 48 \\
\hline ECOG & $<2$ & & & & & & \\
\hline & $\geq 2$ & -21.203 & 1 & .998 & .000 & .000 & \\
\hline $\begin{array}{l}\text { Pattern of positivity } \\
\text { in head \& neck }\end{array}$ & $\begin{array}{l}\text { Nasopharynx } \\
\text { Oropharynx }\end{array}$ & 19.063 & 1 & .998 & 190055855. & .000 & 615 \\
\hline $\begin{array}{l}\text { Positivity in } \\
\text { head \& neck only }\end{array}$ & $\begin{array}{l}\text { No } \\
\text { Yes }\end{array}$ & 1.253 & 1 & .441 & 3.500 & .145 & 84.694 \\
\hline
\end{tabular}

Significant when $\mathrm{p}<0.05$

inter-observer reproducibility and has been validated for PET-CT reporting use at interim and post therapy assessments at the First International Workshop on PET in Lymphoma in Deauville, France and also in several international trials (Barrington et al. 2014). In the criteria, SUVmax is quantified in relation to physiological uptake of mediastinum and liver. A score of 1 (no uptake), 2 (uptake $\leq$ mediastinum) and 3 (uptake $>$ mediastinum but $\leq$ liver) are considered as negative, or complete metabolic response (CMR) in accordance with Lugano Classification for lymphoma response (Barrington \& Kluge 2017; Meignan et al. 2015). A positive PET-CT is defined by FPS score of 
4 (moderate increased uptake compared to the liver) or 5 (marked increased uptake compared to the liver and/or new lesions) and should be referred for confirmatory biopsy.

In HD, PET positivity at end of therapy is associated with adverse risk. In early stage disease, the 2-year failure free survival was $95 \%$ for PET negative patients and $69 \%$ for PET positive patients. In advanced stage disease, PET positivity after BEACOPP therapy had 2-year progression free survival of $82.6 \%$, compared to $92.6 \%$ in patients who achieved PET negativity. Also, PET positive patients receive radiotherapy to the positive lesions (Sher et al. 2009).

To minimize false positivity, PET-CT are performed 6-8 weeks after completion of therapy (Cheson et al. 2007). Surveillance scans are performed at 6 monthly or yearly intervals, or as clinically indicated and the surveillance policy may vary between institutions. In the head \& neck region, the sites commonly infiltrated by lymphoma include Waldeyer's ring, tonsils, nasopharynx and the base of the tongue (Wafa et al. 2009). Anatomically, Waldeyer's ring form the opening to the upper aerodigestive tract and is the initial site of contact between the mucosa-associated lymphoid tissue antigens and the inhaled, ingested or exogeneous antigens. It is laden with reactive lymphoid follicles involved in cell-mediated immune responses, resulting in expansion of inflammatory B cells, T cells and macrophages (Tan 2004). Therefore, focally increased FDG uptake in these areas with benign inflammatory/infectious lesions is commonly observed. We found only two TP lesions, and both were biopsied from the nasopharynx region where the histology demonstrated relapsed mantle cell lymphoma and relapsed DLBCL. The mean SUVmax values of these malignant lesions were $9.0 \pm 2.69$, whilst mean SUVmax of reactive lymphoid hyperplasia lesions were 9.0 \pm 3.88 . Therefore, it appeared that SUVmax values in the head \& neck region were not helpful in differentiating lymphoma from reactive lymphoid hyperplasia, consistent with similar findings reported in other studies (Schaefer et al. 2007). It is now recognised that in Waldeyer's ring, its physiological uptake may be greater than normal mediastinum and/or liver. Complete metabolic response may be inferred if uptake at sites of initial involvement is no greater than surrounding normal tissue even if the tissue has high physiological uptake (NCCN 2018a).

About 30/53 (56.6\%) of our patients received rituximab therapy. Rituximab, an anti-CD20 monoclonal antibody binds to B cells, causes lymphoma cell lysis via complement-mediated cytolysis, antibody-dependent cell cytotoxicity and direct apoptosis. These immune mediated processes lead to inflammation and necrosis, resulting in an increased FDG uptakes (Han et al. 2008). The specificity and PPV were found to be significantly lower for patients receiving rituximab (in R-CHOP) vs. CHOP chemotherapy ( $84 \%$ vs. $87 \%, \mathrm{p}<0.023 ; 23 \%$ vs. $74 \%, \mathrm{p}<0.0001$, respectively), reflecting a higher FP rate in subjects receiving R-CHOP (77\% vs. 26\%, p<0.001) (Avivi et al. 2013). The FP rate remained high for up to 3 years after completion of therapy and rituximab was identified as most significant predictor for false positivity in PET. In contrast, we did not identify rituximab as a risk factor for PET-CT positivity which may be attributed to our small sample size.

Despite significant survival improvement with rituximab in first line therapy for DLBCL, $40 \%$ of patients experience relapse, mainly during the first 2 years after completing therapy (Sehn et al. 2005). Response to salvage therapy is affected by several factors including bulky tumour mass, therefore, it is desirable to adapt a surveillance method that allows detection of early relapse which may improve survival. Different institutions may adapt different protocols for PET-CT surveillance after the completion of first line therapy. However, surveillance approach failed to confirm a survival advantage for patients whose relapse was captured 'pre-clinically' by a routine follow up PET scan (Cohen et al. 2017; Goldschmidt et al. 2011).

In multivariate analysis, we identified HD (age range 23-55 years, data not shown) as a predictor for PET-CT positivity only in the head \& neck region at post therapy and during surveillance $(\mathrm{p}=0.019)$ (Table 4(b)). A study in routine use of PET-CT after completion of therapy in pediatric HD (age range 3-26 years) reported FP rate of $16 \%$ and PPV of $11 \%$ attributed to causes including muscle uptake, brown fat, thymic rebound, and infection/ inflammation (Levine et al. 2006). Although FDG accumulation in the thymus is commonly observed in children, it can also be observed in adults due to thymus hyperplasia after chemotherapy (Brink et al. 2001).

In our study, 106 patients with a total of 435 PET-CT scans were negative in the head \& neck region. The scans were also reported as negative in the whole body area (data not shown). In principle, the calculation for NPV would ideally be based on the demonstration of negative histology taken from the negative PET scans. However, patients may decline to undergo an invasive procedure when there is no clinical indication and especially when the scans were already reported as negative. Therefore, these patients were not referred for biopsy for histological confirmation of true negativity, instead were regarded as TN as they remained negative throughout the study period. Taken together with the fact that PET has consistently demonstrated a high NPV, other reports have also demonstrated that by using this surveillance approach, recurrent or persistent disease can reliably be excluded in patients with negative scan (Schaefer et al. 2007). Consistent with current published data, other authors have defined that a negative PET-CT scan is defined as TN if no further evidence of relapse is found for the next 6-12 months, and conversely the negative scan is considered as FN if relapse is confirmed within the first 6-12 months after imaging. Likewise, a positive scan is regarded as FP if no further evidence of relapse is found for the next 6-12 months (Avivi et al. 2013; Levine et al. 2006).

The PET images and biopsy samples were reported independently by a nuclear medicine physician and a 
TABLE 4. (a) Simple logistic regression for subgroup analysis showed the risk factors associated with PET-CT positivity only in the head \& neck region at post therapy and surveillance

\begin{tabular}{|c|c|c|c|c|c|c|c|}
\hline \multirow{2}{*}{\multicolumn{2}{|c|}{ Variable }} & \multirow[b]{2}{*}{ B } & \multirow[b]{2}{*}{$\mathrm{df}$} & \multirow[b]{2}{*}{$\mathrm{p}$ Value } & \multirow{2}{*}{$\begin{array}{l}\text { Odd } \\
\text { Ratio }\end{array}$} & \multicolumn{2}{|c|}{$\begin{array}{c}\text { 95\% C.I.for } \\
\operatorname{EXP(B)}\end{array}$} \\
\hline & & & & & & Lower & Upper \\
\hline Age & $\begin{array}{l}<60 \\
\geq 60\end{array}$ & -1.269 & 1 & .001 & .281 & .134 & .589 \\
\hline Gender & $\begin{array}{l}\text { Male } \\
\text { Female }\end{array}$ & -1.050 & 1 & .017 & .350 & .148 & .828 \\
\hline Stage & $\begin{array}{c}\text { I \& II } \\
\text { III \& IV }\end{array}$ & -1.281 & 1 & .011 & .278 & .103 & 0.748 \\
\hline $\begin{array}{l}\text { Subtype } \\
\text { lymphoma }\end{array}$ & $\begin{array}{l}\mathrm{HD} \\
\mathrm{NHL}\end{array}$ & -1.735 & 1 & .006 & .176 & .052 & .602 \\
\hline Extra-nodal & $\begin{array}{l}\text { No } \\
\text { Yes }\end{array}$ & -.981 & 1 & .012 & .375 & .174 & 0.807 \\
\hline ECOG & $\begin{array}{l}<2 \\
\geq 2\end{array}$ & -1.099 & 1 & .001 & .333 & .178 & .624 \\
\hline $\begin{array}{l}\text { B symptoms at } \\
\text { diagnosis } \\
\text { Rituximab } \\
\text { therapy }\end{array}$ & $\begin{array}{l}\text { No } \\
\text { Yes } \\
\text { No } \\
\text { Yes }\end{array}$ & $\begin{array}{l}-1.099 \\
-1.558\end{array}$ & 1 & $\begin{array}{l}.033 \\
.005\end{array}$ & $\begin{array}{l}.333 \\
.211\end{array}$ & .121 & 0.917 \\
\hline $\begin{array}{l}\text { Pattern of positivity } \\
\text { in head \& neck }\end{array}$ & $\begin{array}{l}\text { Nasopharynx } \\
\text { Oropharynx }\end{array}$ & -1.322 & 1 & .019 & .267 & .089 & 0.803 \\
\hline
\end{tabular}

Significant when $\mathrm{p}<0.05$

TABLE 4. (b) Multiple logistic regression in subgroup analysis showed that Hodgkin Disease (HD) subtype was identified as a predictor for PET-CT positivity only in the head \& neck region at post therapy and surveillance

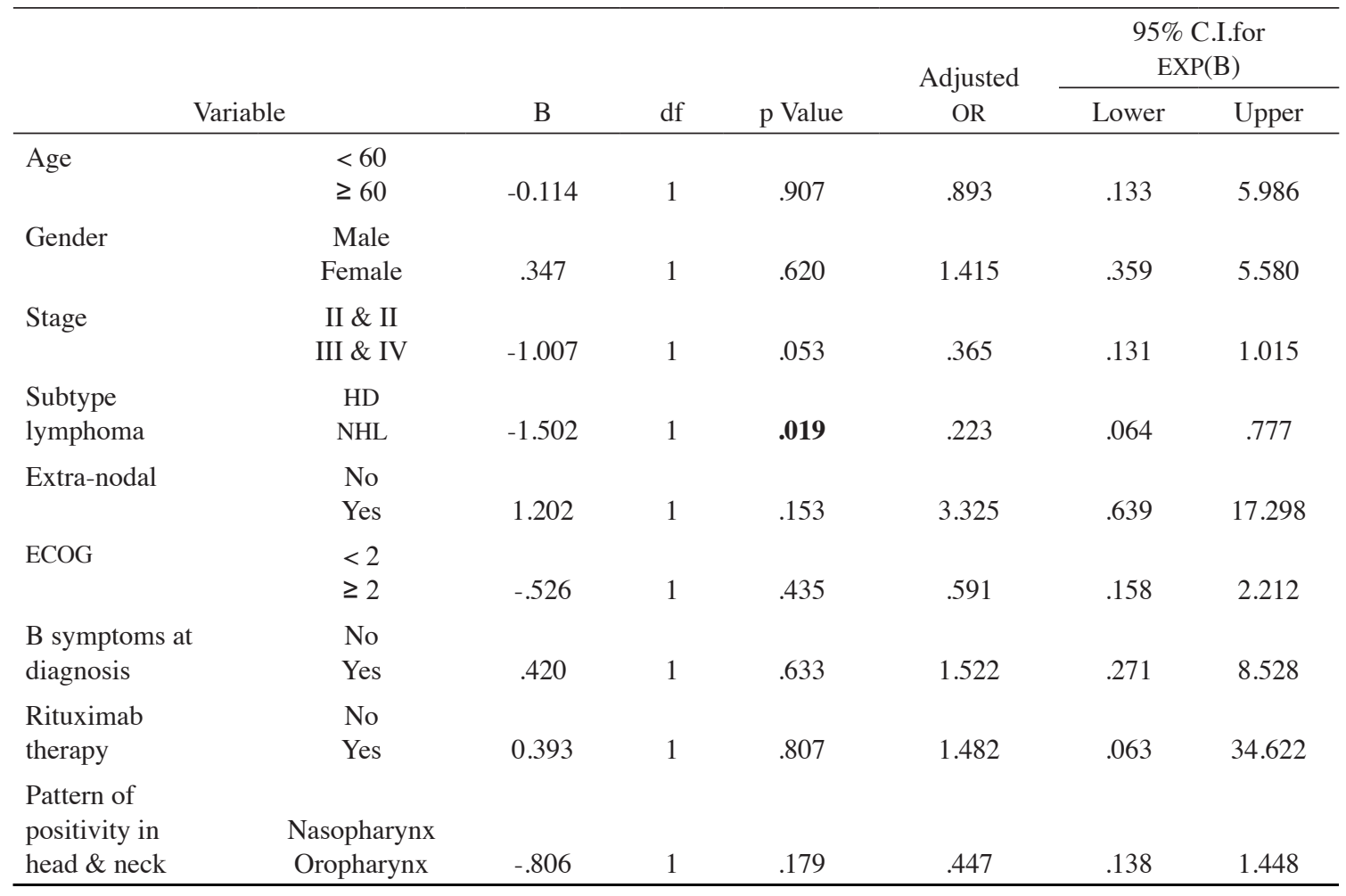

Significant when $\mathrm{p}<0.05$ 
consultant histopathology's in the same centre, with each reviewer blinded to the correlation between the results of the scans and biopsy. Due to limited research resources, the images or biopsy samples were not re-reviewed again by external reviewers from different centres.

Our study was limited by the small sample size and the relatively short follow up period. Every effort has been taken to reduce the rate of false positivity caused by infections or inflammation. However, these confounding factors may be quite difficult to control as patients may still feel well with sub-clinical infections. Apart from direct visualization of the tonsils during tonsillectomy, biopsy location in other sites within the head \& neck region was 'best guess' as guided by the preceding PET-CT images, and in fact may not be entirely representative of the hypermetabolic lesion seen on the scan, hence may lead to 'false positivity'.

\section{CONCLUSION}

Positive PET-CT scans in the head \& neck region at post therapy and surveillance were associated with high false positivity due to reactive lymphoid hyperplasia, with little value in determining remission status. Biopsy of positive FDG avid lesions remains the gold standard for confirming new or persistent disease at the end of therapy. Clinical and pathological correlation is required and management decisions should not be based on PET scan result alone. PET-CT scans should not be routinely performed due to risk of FP and unnecessary diagnostic interventions and/or radiation exposure. Patients with negative PET-CT scan in the head \& neck region at post therapy may be followed up with clinical history, physical examinations and laboratory tests. HD was predicted to be more likely to have PET-CT positivity only in the head \& neck compared to NHL. The role of PET-CT surveillance remains controversial, and further studies are needed to determine its value in detecting true lymphomatous relapse in selected high-risk patients.

\section{ACKNOWLEDGEMENTS}

We thank the Dean, Faculty of Medicine UKM, the Director of UKMMC, the Commanding Officer and Physicians of Hospital Angkatan Tentera Tuanku Mizan.

\section{REFERENCES}

Ancey, P.B., Contat, C. \& Meylan, E. 2018. Glucose transporters in cancer: From tumor cells to the tumor microenvironment. The FEBS Journal. https://doi.org/10.1111/febs.14577.

Avivi, I., Zilberlicht, A., Dann, E.J., Leiba, R., Faibish, T., Rowe, J.M. \& Bar-Shalom, R. 2013. Strikingly high false positivity of surveillance FDG-PET/CT scanning among patients with diffuse large cell lymphoma in the rituximab era. American Journal of Hematology 88(5): 400-405.

Barrington, S.F. \& Kluge, R. 2017. FDG PET for therapy monitoring in Hodgkin and non-Hodgkin lymphomas. European Journal of Nuclear Medicine and Molecular Imaging 44(1): 97-110.
Barrington, S.F., Mikhaeel, N.G., Kostakoglu, L., Meignan, M., Hutchings, M., Müeller, S.P., Schwartz, L.H., Zucca, E., Fisher, R.I. \& Trotman, J. 2014. Role of imaging in the staging and response assessment of lymphoma: Consensus of the International Conference on malignant lymphomas imaging working group. Journal of Clinical Oncology 32(27): 3048-3058.

Brink, I., Reinhardt, M.J., Hoegerle, S., Altehoefer, C., Moser, E. \& Nitzsche, E.U. 2001. Increased metabolic activity in the thymus gland studied with^ $1^{\wedge} 8$ F-FDG PET: Age dependency and frequency after chemotherapy. Journal of Nuclear Medicine 42(4): 591-595.

Cheson, B.D., Fisher, R.I., Barrington, S.F., Cavalli, F., Schwartz, L.H., Zucca, E., Lister, Alliance, Australasian Leukaemia and Lymphoma Group., Eastern Cooperative Oncology Group., European Mantle Cell Lymphoma Consortium., Italian Lymphoma Foundation., European Organisation for Research., Treatment of Cancer/Dutch Hemato-Oncology Group., Grupo Español de Médula Ósea., German HighGrade Lymphoma Study Group., German Hodgkin's Study Group., Japanese Lymphorra Study Group., Lymphoma Study Association., NCIC Clinical Trials Group., Nordic Lymphoma Study Group., Southwest Oncology Group. \& United Kingdom National Cancer Research Institute. 2014. Recommendations for initial evaluation, staging, and response assessment of hodgkin and non-Hodgkin lymphoma: The Lugano classification. Journal of Clinical Oncology 32(27): 3059-3068.

Cheson, B.D., Pfistner, B., Juweid, M.E., Gascoyne, R.D., Specht, L., Horning, S.J., Coiffier, B., Fisher, R.I., Hagenbeek, A. \& Zucca, E. 2007. Revised response criteria for malignant lymphoma. Journal of Clinical Oncology 25(5): 579-586.

Cohen, J.B., Behera, M., Thompson, C.A. \& Flowers, C.R. 2017. Evaluating surveillance imaging for diffuse large B-cell lymphoma and Hodgkin lymphoma. Blood 129(5): 561-564.

Fadilah Abdul Wahid. 2009. Fundamentals of the management of non-Hodgkin lymphoma. Medical Journal of Malaysia 64(4): 333-340.

Goldschmidt, N., Or, O., Klein, M., Savitsky, B. \& Paltiel, O. 2011. The role of routine imaging procedures in the detection of relapse of patients with Hodgkin lymphoma and aggressive non-Hodgkin lymphoma. Annals of Hematology 90(2): 165-171.

Han, H.S., Escalon, M.P., Hsiao, B., Serafini, A. \& Lossos, I.S. 2008. High incidence of false-positive PET scans in patients with aggressive non-Hodgkin's lymphoma treated with rituximab-containing regimens. Annals of Oncology 20(2): 309-318.

Kazama Toshiki, Silvana C Faria, Vithya Varavithya, Sith Phongkitkarun, Hisao Ito \& Homer A. Macapinlac. 2005. FDG PET in the evaluation of treatment for lymphoma: Clinical usefulness and pitfalls. Radiographics 25(1): 191207.

Levine, J.M., Weiner, M. \& Kelly, K.M. 2006. Routine use of PET scans after completion of therapy in pediatric Hodgkin disease results in a high false positive rate. Journal of Pediatric Hematology/Oncology 28(11): 711-714.

Meignan, M., Hutchings, M. \& Schwartz, L.H. 2015. Imaging in lymphoma: The key role of fluorodeoxyglucose-positron emission tomography. The Oncologist 20(8): 890-895.

Moskowitz, C.H. 2012. Interim PET-CT in the management of diffuse large B-cell lymphoma. ASH Education Program Book 2012(1): 397-401. 
Myers, E.N. 2010. Head and neck oncology-2010, Part I. Otolaryngologia Polska 64(3): 136-146.

National Comprehensive Cancer Network (NCCN). 2018a. B-Cell Lymphomas. Accessed on 21 January 2019.

National Comprehensive Cancer Network (NCCN). 2018 b. Hodgkin Lymphoma. Accessed on 21 January 2019.

Rahmouni, A., Luciani, A. \& Itti, E. 2005. MRI and PET in monitoring response in lymphoma: Wednesday 5 October 2005, 08: 30-10: 00. Cancer Imaging 5: S106-S112.

Sarji, S. Ahmad. 2006. Physiological uptake in FDG PET simulating disease. Biomedical Imaging and Intervention Journal 2(4): 59. doi: 10.2349/biij.2.4.e59.

Schaefer, N.G., Taverna, C., Strobel, K., Wastl, C., Kurrer, M. \& Hany, T.F. 2007. Hodgkin disease: Diagnostic value of FDG PET/CT after first-line therapy-Is biopsy of FDG-avid lesions still needed? Radiology 244(1): 257-262.

Sehn, L.H., Donaldson, J., Chhanabhai, M., Fitzgerald, C., Gill, K., Klasa, R., MacPherson, N., O’Reilly, S., Spinelli, J.J. \& Sutherland, J. 2005. Introduction of combined CHOP plus rituximab therapy dramatically improved outcome of diffuse large B-cell lymphoma in British Columbia. J. Clin. Oncol. 23(22): 5027-5033.

Sher, D.J., Mauch, P.M., Van Den Abbeele, A., LaCasce, A.S., Czerminski, J. \& Ng, A.K. 2009. Prognostic significance of mid-and post-ABVD PET imaging in Hodgkin's lymphoma: The importance of involved-field radiotherapy. Annals of Oncology 20(11): 1848-1853.

Tan, L.H.C. 2004. Lymphomas involving Waldeyer's ring: Placement, paradigms, peculiarities, pitfalls, patterns and postulates. Annals-Academy of Medicine Singapore 33: 15-26.

Wafa Allam, Nabil Ismaili, Sanaa Elmajjaoui, Bel K Elgueddari, Mohammed Ismaili \& Hassan Errihani. 2009. Primary nasopharyngeal non-Hodgkin lymphomas: A retrospective review of 26 Moroccan patients. BMC Ear, Nose and Throat Disorders 9(1): 11. https://doi.org/10.1186/1472-6815-9-11.

Zinzani, P.L., Stefoni, V., Tani, M., Fanti, S., Musuraca, G., Castellucci, P., Marchi, E., Fina, M., Ambrosini, V. \& Pellegrini, C. 2009. Role of [18F] fluorodeoxyglucose positron emission tomography scan in the follow-up of lymphoma. J. Clin. Oncol. 27(11): 1781-1787.

Wan Fariza Wan Jamaludin*, Seery Zaliza Azura Zaider \& S Fadilah Abdul Wahid

Pusat Terapi Sel

Universiti Kebangsaan Malaysia Medical Centre

Jalan Yaacob Latif, Bandar Tun Razak

56000 Cheras, Kuala Lumpur, Federal Territory

Malaysia

Fara Rahidah Husin

Department of Medicine

Universiti Kebangsaan Malaysia Medical Centre

Jalan Yaacob Latif, Bandar Tun Razak

56000 Cheras, Kuala Lumpur

Malaysia
Aini Ab. Aziz

Department of Nuclear Medicine

Universiti Kebangsaan Malaysia Medical Centre

Jalan Yaacob Latif, Bandar Tun Razak

56000 Cheras, Kuala Lumpur, Federal Territory

Malaysia

Aini Ab. Aziz

Department of Radiology

National Heart Institute of Malaysia

145, Jalan Tun Razak, Bandar Tun Razak

50400 Kuala Lumpur, Federal Territory

Malaysia

Mohd Razif Mohd Yunus, Mawaddah Azman \& Kong Min Han Department of Otorhinolaryngology

Universiti Kebangsaan Malaysia Medical Centre

Jalan Yaacob Latif, Bandar Tun Razak

56000 Cheras, Kuala Lumpur, Federal Territory

Malaysia

Noraidah Masir \& Mahdieh Ghoddoosi

Department of Pathology

Universiti Kebangsaan Malaysia Medical Centre

Jalan Yaacob Latif, Bandar Tun Razak

56000 Cheras, Kuala Lumpur, Federal Territory

Malaysia

Normi Mustapha

Faculty Science \& Technology

Open University Malaysia

Jalan Tun Ismail, 50480 Kuala Lumpur, Federal Territory

Malaysia

Nor Asiah Muhamad

Non Communicable Disease Section

Ministry of Health

Complex E, Federal Government Administrative Building 62590 Putrajaya, Federal Territory

Malaysia

*Corresponding author; email: wanfariza@ppukm.ukm.edu.my

Received: 24 January 2019

Accepted: 3 September 2019 